\title{
Progressing Yet Unsettled: Study on Chinese College English Policies from 1980
}

\author{
Guijun Zhang \\ China Pharmaceutical University, Nanjing, China \\ Email: zgj100@aliyun.com
}

Received 1 May 2016; accepted 6 August 2016; published 10 August 2016

Copyright (C) 2016 by author and OALib.

This work is licensed under the Creative Commons Attribution International License (CC BY). http://creativecommons.org/licenses/by/4.0/

(c) (i) Open Access

\begin{abstract}
English teaching and learning in Chinese higher education are unique in that it is guided by Chinese Ministry of Education. The paper first elaborates the main features and differences of official College English teaching syllabuses $(1980,1985 / 1986,1999)$ and requirements $(2004 / 2007)$ for non-English undergraduates issued by the Chinese Ministry of Education after the economic reform and opening up. The syllabuses and requirements are outlined in accordance with the English education developments and the requirements of the socioeconomic development of China in different times. They are guidelines of the College English education to be observed nationwide and direct the English teaching and studying in Chinese colleges and universities. Second, some present problems are cogitated following the discussion: the negative influence of CET, imbalanced education level nationwide, rising English level of middle school graduates, and the choice between English for General Purpose or English for Specific Purpose (ESP). All these will influence the College English syllabus drafts in the future.
\end{abstract}

\section{Keywords}

College English, Syllabus, Problems, Policies

Subject Areas: Education

\section{Introduction}

Chinese education is governed and directed by the Ministry of Education (MOE), which exerts its power by issuing official documents to be implemented by schools of different levels in China. The contents listed in the documents are modified or changed in accordance to the socioeconomic and educational developments. On the national level, English language education has been viewed by the Chinese leadership as having a vital role to play in national modernization and development (Ross, 1992 [1]; Adamson \& Morris, 1997) [2]. In retrospect of Chinese English teaching, we find that every reform is initiated from the drafts and revisions of official docu- 
ments formulated by a group of experts in College English Advisory Committee under the Department of Higher Education, MOE. College English refers to the English as foreign language learning for all non-English major students in China. The research focuses on the comparison of national College English teaching syllabuses or requirements designed for non-English major college and university students in different historical periods after the economic reform and opening up. This paper consists of two parts: the first part analyses the features and differences of different college English teaching documents and the second one discusses some problems yet to be solved in the future.

\section{Analysis and Comparison of the Main National Documents}

China determined the policy of Reform and Opening up in the third Plenary Session of the Communist Party of China in 1978. She resumed the Higher Entrance Examination that had been suspended for 10 years in the Cultural Revolution in the winter of 1977 for the urgent need of talents in all professional fields. Since then, China has been exploring effective English teaching approaches for decades, which is embodied in official policy documents in different developing periods. In this part, official documents are listed and analyzed: the 1980's [3], 1985/1986's [4] [5] and 1999's policies called "syllabus" [6], and the 2004/2007's called "curriculum requirements" [7].

\subsection{College English Teaching Syllabus 1980 (Draft)}

In 1977, China resumed College Entrance Examination to enroll higher education students but it wasn't until 1983 that foreign language examination results were included in the total score as one of the admission criteria. English teaching syllabus trial for science and engineering undergraduates (draft) (Editing and Education Committee of Public College English Textbooks of Sciences and Engineering, 1980) was enacted in 1980, which was designed to end the chaos of English teaching at the time, unify the requirements of college English teaching for the colleges and universities nationwide and establish the official status of English in higher education. The 1980 syllabus first stipulated different requirements for students with different English levels. If the students had reached the requirements for college entrance criteria, they directly entered the second stage of learning. In the second stage, they could choose English translation and writing courses. Second, it explicitly proposed the goals of the listening, speaking, writing skills. Third, academic reading was formally requested in the syllabus (Cai, 2009) [8]. Though it was structurally loose and informal with only the grammar teaching contents stipulated (Han, 1999) [9], and there was not description of general goals, the syllabus laid a foundation for the following national syllabuses and increased the motivation in learning English of the college students. In other words, it is more symbolic than practical significance in that it signifies "back to learn English".

\subsection{5' and 1986's Syllabuses}

With the implementation of the Reform and Opening policy, the demands for college graduates' English proficiency also rose and the requirements of the 1980's syllabus could not meet the demand. Middle school students' English level had greatly improved through several years of educational recovery. For example, the vocabulary for middle school graduates reached 1600 words and phrases approximately (Deng, 2001). Meanwhile, Because of the gradual perfection in the education system, and the accumulation of college English teachers' experiences, the overall level of foreign language teaching in China was greatly increased.

In 1985, the MOE issued College English Teaching Syllabus (for Science and Engineering Majors) (College English Syllabus Revision Team, 1985) and demanded the relevant universities to implement it from the fall semester in 1988. In November, 1985, College English Teaching Syllabus (for Arts and Sciences majors) was edited (College English Syllabus Revision Team, 1986) and was issued by MOE in the following year. The two syllabuses were formulated separately because college English contents for Science and Arts students were regarded as different. In essence, the two syllabuses have no fundamental distinction, and both determine the dominance of English reading skills. They are usually bracketed as 1985/1986 syllabuses. Syllabuses 1985/1986 prove the necessity and feasibility of applying the syllabuses universally in both the Arts and Sciences English teachings. The teaching purposes, course content and arrangement, the principle in textbooks editing and testing are also made clear to ensure the universal application of the syllabuses. The main features are discussed in the follows. 


\subsection{Attaching Importance to Basic English the Teaching}

Syllabus 1980 only emphasized scientific reading, while the 1985/1986 syllabuses stated that the purpose of college English education was to cultivate "a relatively high ability in reading, a moderate ability in listening, and an elementary ability in writing and speaking so that the students will be able to employ English as a means for getting information necessary for pursuing their specialty. In addition, it will help the students lay a good foundation for further progress in studying English.” (College English Syllabus Revision Team, 1985/1986). Besides the usual requirements as the previous syllabus for reading skills, the syllabus lists the requirements for listening, speaking and writing, which are stipulated for the first time in history. Reading is considered as the most important skill to Chinese students because it is the main means to learn from western countries, but the importance of other skills beneficial to language mastery is attended to although the requirements are relatively low at the time.

In the teaching content section, the syllabus 1985/1986 explicitly stipulate basic vocabulary, basic grammar and basic skills in reading, listening, writing and speaking. In the textbook editing section, the syllabuses indicate that the theme and genre of textbooks should be extensive; emphasizing the chosen articles and materials should fit the language foundation. The testing section says, “... should focus on assessment of the language foundation” (College English Syllabus Revision Team, 1985/1986).

\subsection{Determination of Level-Based English Teaching}

According to the syllabuses 1985/1986, English teaching is divided into six bands. The fourth band is indicative of attaining the basic requirements and sixth band of intermediate requirements. "After finishing band 4 and 6 , students are required to organize national English tests according the syllabus." (College English Syllabus Revision Team, 1985/1986) The tests are generally referred to as the College English Test (CET) band 4 and band 6. Each level had qualitative and quantitative requirements. Take reading in CET4 for example, students should master basic reading skills and be able to read English texts with relative difficulty at a speed of 50 words per minute.CET4 and CET6 were conducted for the first time in September, 1987 and January, 1989 respectively. Now CET is the biggest English test in the world with around 10 million participants yearly.

\subsection{Syllabus (Revision) 1999}

With the deepening of Chinese economic reforms and more foreign exchange, the requirements of English application for college students rose accordingly. The previous syllabuses had lagged behind the time and need revising.

Although there is a list of micro skills of language in syllabuses 1985/1986 to be mastered, only the students reading skill performance was satisfactory. More and more graduates obtain CET Band 4 or 6 certificates, but their English proficiency is not necessarily high. Take English speaking for example, "mute English" is always been criticized by the students and employers. The reason for it is that the speaking requirements in syllabuses 1985/1986 are low and some colleges and universities only emphasize on the CET 4 and 6 passing rate but ignore the teaching of "speaking" which is not included as a compulsory part in CETs.

After several years' investigation and study, the syllabus made the appropriate adjustments in College English Teaching Syllabus (Revision) (College English Syllabus Revision Team, 1999) based on the researches on language teaching and learning, and with reference to the current middle school English syllabus. It connected higher education requirements with the current middle school English teaching syllabus, to make middle school and college English learning coherent. Compared with the previous syllabuses, the Syllabus shows the following features:

\subsection{Emphasizing Information Exchange in English}

In Syllabus 1999, English teaching is "to cultivate students with a relatively high level of competence in reading, and an intermediate level of competence in listening, speaking, writing and translating, so that they can exchange information in English" (College English Syllabus Revision Team, 1999). New syllabus proposes "to cultivate students' ability to exchange information in English," It is higher than the previous "English as a tool for needed professional information” (College English Syllabus Revision Team, 1985/1986). 


\subsection{Heightening All Language Skill Requirements}

Take reading for example, the reading speed should be 70 words per minute rather than 50 in the 1985/1986 syllabuses. Reading is considered as the foundation for mastering language knowledge, accessing to foreign information, and improving listening, speaking, reading, writing and translating abilities. Therefore, College English teaching always pays attention to the cultivation of reading ability. The content was also broadened in that it not only requires good English reading skills, but also requires students to understand English by listening, communicate orally and can write in English. The syllabus changes the requirements of the students' language application ability from the three tiers of the syllabuses into two: reading is the first level of requirements, listening, speaking, writing and translating as the second tier, which is a major revision in this new syllabus. After years of reform and opening up and reform of high school and college English teaching, the students are eager to improve speaking and writing ability. Thus improving students' reading, listening, speaking, writing and translating abilities has become increasingly important.

\subsection{Emphasizing Self-Motivated Learning}

The syllabus also points out that college English teaching should help students to master good language learning methods, and improve the cultural awareness. Student is the main body of teaching and inputted knowledge need be understood and absorbed by the students themselves, that is, the cultivation of the ability depends on the students' English practices; English learning is a long-term process, and students need to study hard constantly to improve English level. Therefore, teachers have the responsibility to consciously cultivate the students' language sense in daily teaching, help them form good habits of language learning by improving the ability of selfstudy by the students.

\subsection{Elaborating on the Description of Level Requirements}

The syllabus establishes that basic requirements national Band 4 examination should be met by all kinds of institutions of higher learning. When the syllabus 1986 was issued, it just put forward "key school students who learn starting from preparation stage must finish learning four levels English. Students of other colleges should reach level prescribed by their schools" (College English Syllabus Revision Team, 1985/1986) according to the actual situation of the time. After ten years of efforts, the overall level of college English has been increased considerably, at the same time due to the needs of the national economic development and international exchanges the syllabus stated that even in non-key colleges and universities, students starting from the preparation level should reach level 3 after two years of learning, but in the senior stage they should also continue to work hard to reach level 4 . Schools should provide the necessary teaching environments.

\subsection{Requiring Four-Year English Learning Continuously}

This syllabus changed specialized English reading into specialized English, so as to make more clear this stage of the teaching mission. Specialized English is a compulsory course outlined clearly by the syllabus, and requirements for specialized English reading, listening, speaking, writing and translating skills are put forward specifically, thus making the schools of specialized English teaching has guidelines to depend on. In order to make students English level in the university increase steadily, it also proposes the suggestion of an English level test before graduation, prompting the schools to take steps to ensure that continuous English learning in the four years of college, motivate students to make full use of the advantage of the school, and continue to improve the English application ability.

\subsection{College English Curriculum Requirements 2004/2007}

After entering the 21st century, China's college English teaching faced more challenges. First, with China's joining World Trade Organization, international communication became increasingly frequent. The country urgently needed professionals with high English level to participate in international competition. Second, China's colleges and universities expanded student enrollment every year from 1998. Along with the rising number of college students, the problem of faculty insufficiency became increasingly severe. Third, although the achievements of college English teaching in the past years and the English level of college graduates had improved 
greatly, it was admitted that students' practical application competence was still weak. Fourth, the college English curriculum, compared with syllabuses 1985/1986, was almost the same in that teaching content, means and mode, etc. Fifth, there was unbalanced socioeconomic and education development of regions and the problem will exist for a long time in the future. Last, according to the Curriculum Criteria for Senior High School Requirements for high school students, excellent level was 4500 words; basic requirements also reached 2400-2500 words (MOE, 2003) [10]. It is much higher than the previous requirements.

In this context, the MOE launched college English teaching reform project in 2002. In 2004 the Ministry of Education issued the College English Curriculum Requirements (trial draft) which was first tried in 180 universities in different regions nationwide. In 2007, it was issued officially after a three-year trial. It is noticeable that is the first time the official document uses "curriculum" instead of "syllabus" to name national educational document. The transition together with "requirements" denotes the MOE considers it as a general guideline. It is because schools of higher education differ greatly from each other in terms of teaching resources and students' English level, etc. Colleges should be granted more freedom to formulate their own syllabuses considering the differences between different regions, different students, thus making the education authorities to determine according to their own situation to achieve the contents of the curriculum and avoids the defects of single target for different regions and students.

The purpose indicated in "College English Curriculum Requirements" is to "cultivate students' comprehensive application ability, especially listening and speaking ability, make them effectively communicate in English in both written and spoken means in the future work and social activities, improve their ability of autonomous learning, and raise the comprehensive cultural awareness to meet the need of social development in our country and international communication" (Ministry of Education, 2007). What the course requirements emphasize is the language comprehensive skills, especially listening and speaking, in contrast, syllabuses 1985/1986 and 1999 give priority to basic skills and focus on training students' reading in English as the main goal of college English.

Teaching requirements of college English are divided into three levels, namely the general, high and higher requirements. Compared with the former two syllabuses, Requirements 2007 put forward suitable standards by adapting to the situation of high school English at that time and suiting to the language application purposes. The general requirement must be achieved by every college graduates. College freshmen who have achieved or not 7th grade of "high school English curriculum standard" can set it as the aim of college English learning. High and higher requirements are for those who have reached $8^{\text {th }}$ or $9^{\text {th }}$ grade in middle schools. These three requirements all include English language knowledge and application skills, learning strategy and cross-cultural communication contents (Ministry of Education, 2007).

A computer- and classroom-based multimedia College English teaching model is provided in Requirements 2007 to help students achieve the objectives set by the requirements. The model places a premium on individualized teaching and independent learning and makes full use of the special function of computers in assisting learners with individualized and repeatable language practice, especially with the training of the listening and speaking abilities. From the perspective of learners, this means a switch to a learner-centered model that allows more learner autonomy by making the teaching and learning a computer-based process of individualized learning, collaborative learning and hyper-textual learning. This humanistic teaching feature is unprecedented in the previous syllabuses, and reflects that our teaching notions are shifting from how to teach to how to learn.

Teaching evaluation is divided into formative assessment and summative assessment. Proper assessment provides backwash for ensuring the quality of learning. Considering autonomous learning characteristics of the multimedia teaching, formative assessment in practice is especially important in practice and beneficial in raising students' autonomous learning consciousness.

In sum, Syllabus (draft) 1980 lays emphasis on grammatical analysis. Syllabuses 1985/1986 continue to lay good foundation of language skills to enable students to get information by using English as a tool. Although Syllabus 1999 adds that English teaching should enable students to communicate in English, only reading is given priority. In general, language teaching is limited to language usage in the previous syllabuses. Requirements 2004/2007 bring out a revolutionized change in setting the objective of College English teaching, which is to develop students' competence to use English comprehensively, especially in listening and speaking, to exchange information effectively. Two reasons can account for the shifting objectives of college English teaching from language analysis to language competence. First, English language education in China has been inextricably linked to political, economic, and social development in the country. These policies have been shaped by the 
changing contexts of national development. With the deepening of reform and opening up and China's entry into the WTO, exchanges with foreign countries are greatly increased and will be more, thus causing a demand for better communicative competence. Second, theoretical development in language teaching and learning researches and technology developments have also contributed to the policy making. Take teaching methods for example, Syllabus(draft) 1980 and Syllabuses 1985/1986 are influenced by Grammar-translation method, Syllabuses 1999 begins to intake some ideas in communicative language teaching, Requirements 2007 advocates learner-centered autonomous learning by using modern technology.

\section{More Problems to Be Settled}

After 30 plus years of development, especially the teaching reform of college English in recent years, college English has developed from a single language teaching curriculum which focuses on reading into a comprehensive curriculum system. College English curriculum goals are based on the massive social English ability requirement analysis; the content of college English teaching is expanding, covering the language knowledge and skills, learning strategies, cultural accomplishment, the intercultural communication ability and so on; college English teaching materials and teaching system are more and more diverse; the teaching modes and teaching methods are reformed and innovated continuously. However, there are problems arising for consideration and modification.

\subsection{The Impact of CET}

Since the launching of CET, the motivation and enthusiasm for English studying is greatly stimulated. CET's contributions to China's college English education receive praise and affirmation, but it also exerts a negative influence on the college English teaching. At present, many colleges and universities (especially general colleges and universities) still consider the CET test scores as a criterion for granting student degree and evaluating teachers' performance Although MOE never stipulate so, but just as Nunan (1988) [11] says, there is frequent mismatch between what was planned and what actually occurs in the language classroom. The tests lead teachers to an exam-oriented teaching and schools' curriculum and textbooks are mainly designed in favor of helping students pass the test, thus neglecting the students' language proficiency. There are consistent criticisms from the society that the students with a high CET results can not apply English in the real working place, not to mention international communication ability and competitiveness in their own professional field.

\subsection{Imbalanced Education Level Nationwide}

China is a big country with an unbalanced development in economy and education in various regions. Meanwhile students in different majors and school have different needs in English. College English teaching should develop in the direction of individualization and diversification, but the syllabuses, including College English curriculum requirements unify demands in general. It will certainly bring problems and defects. It is suggested that the next college English education policy in English education should replace the unified teaching requirements (Cai, 2009). College English teaching requirements, teaching contents and teaching methods should reflect the personalized, localized and diversified characteristics of different schools instead of the nation's one size fits all policy.

\subsection{Rising English Level of Middle School Students}

Scrutinizing the present high school English curriculum standard, it is not hard to find high school teaching objectives, curriculum setting, teaching requirements are fundamentally no different with college English requirements. The former teaching goal is also "to cultivate the students' comprehensive language using ability" (MOE, 2003). The requirement of high school graduates of English vocabulary is 3300 - 4500. The latter also put forward the goal of college English teaching is to develop students' comprehensive application ability. And for college students to meet the basic requirements, their vocabulary is only 4500. Feng Yan (2010) conducted the survey of 32 colleges and universities directly supervised by the MOE and found a lot of students entering universities had reached a corresponding level of CET4. As the improvement of middle school English teaching, "in colleges and universities, especially the key universities, college English course has lost the reasons for existence” (Feng, 2010) [12]. 


\subsection{English for General Purposes or for Specific Purposes}

Syllabuses 1985/1986 stipulated that "College English teaching must focus on language fundamentals. Syllabus 1999 again outline the goal of college English teaching is" to help students lay the solid language foundation. Course Requirements 2007 puts forward "to help students to lay a solid language foundation, and also cultivate their strong practical application ability, especially listening and speaking skills. Too much emphasizing basic English leads to the problems of exam-oriented teaching, boredom and low learning efficiency.

In recent years, more and more foreign language scholars support the proposal of position adjustment in English teaching. Shu (2011) pointed out, “college English teaching should serve China’s higher education internationalization. According to this goal, our college English teaching, teachers, course requirements, training, teaching evaluation and so on will need a revolutionary adjustment. It is also the university English fundamental reform which has been waited for a long time.” [13].

The proposal of supporting the English for Specific Purposes (ESP) is prevailing in CET experts. Lu (2010) pointed out: "in the light of the primary, secondary and university English teaching content repetition, English teaching should be re-positioned. Primary and secondary school English teaching should focus on basic work, and college and graduate English teaching should be academic English teaching.” [14].

The purpose of ESP teaching is to meet the needs of making the learners to work or research in English more professionally. It's content-based language teaching. In theory, Students learning efficiency will also be higher because content-based language teaching may increase motivation in studying English. Mohan \& Beckett (2003) says, "There is wide agreement among researchers that content-based language learning (CBLL) instruction is most effective when it provides both meaningful communication about content and intentional language development" [15]. But it is not necessarily the case in China.

ESP teaching requires teachers to use English to teach contents pertaining to students' majors. But while teaching academic English, college English teachers may face many obstacles concerning them, namely the vocabulary, syntax, genre, structure, the professional terminology and professional knowledge, etc. And the same academic knowledge elaborated in English is much more difficult understood than in native language. In addition, students also need more efforts to understand academic knowledge, especially when concepts are complicated, thus sacrificing the efficiency and effect of academic studies.

The college English syllabuses 1986/1999 provide guidelines for ESP reading training. It is required that after finishing general studies, students should continue to learn academic English reading for three semesters, altogether more than 100 class hours. And academic English literature reading, academic English translation, English abstract writing, etc. are suggested to be included in the eighth semester. Requirements 2007 also has similar requirements. But in practice very few colleges conform to or the requirements. Many problems are yet to be solved in ESP teaching in China: The statue of the ESP teaching is unknown; the nature and teaching principles are unclear; how to teach ESP needs studying; college English teachers have not relevant academic background, etc. There have always been tit-for-tat arguments about teaching basic knowledge and skills or conducting ESP.

\section{Conclusion}

With the development of the Chinese economy, MOE proposes different requirements for English teaching at higher education level. College English syllabuses or requirements have always kept paced with socioeconomic and English education progress at various times accordingly. It is inevitable that we need a new national educational document soon. Whether to hold the tradition of teaching basic English or make a fundamental change into teaching ESP is yet to be settled in the near future. Educational level and undergraduates' English level in China are diversified greatly from rather low level to native-speakers level. As a national education policy maker, MOE has to consider the situation of colleges and universities in underdeveloped regions or levels to promote equality in education. And there is no consensus as to what kind of standard is the criterion of having obtained the language comprehensive skills, especially listening and speaking. ESP teaching means different learning objectives, course materials, environment, evaluation, etc. Perhaps the biggest challenge is that most English professionals do not have specialized training in ESP. In addition, ESP researchers must continue to develop the convergence between research, teaching, and learning as the English education in China continues to advance so that the national syllabus or requirement can adjust to fit the Chinese context. 


\section{Acknowledgements}

I would like to show my gratitude to Professor James Collins, State University of New York at Albany,who helped me revise the paper.

\section{References}

[1] Ross, H. (1992) Foreign Language Education as a Barometer of Modernization. In: Hayhoe, R., Ed., Education and Modernization: The Chinese Experience, Pergamon, Oxford, 239-254.

[2] Adamson, B. and Morris, P. (1997) The English Curriculum in the People's Republic of China. Comparative Education Review, 41, 3-26. http://dx.doi.org/10.1086/447413

[3] Editing and Education Committee of Public College English Textbooks of Sciences and Engineering (1980) English Teaching Syllabus Trial for Science and Engineering Undergraduates (Draft). People’s Publishing House, Beijing.

[4] College English Syllabus Revision Team (1985) College English Teaching Syllabus (for Students of Science and Engineering Majors). Shanghai Foreign Language Education Press, Shanghai.

[5] College English Syllabus Revision Team (1986) College English Teaching Syllabus (for Students of Arts and Sciences Majors). Shanghai Foreign Language Education Press, Shanghai.

[6] College English Syllabus Revision Team (1999) College English Teaching Syllabus (for Regular College Students). Shanghai Foreign Language Education Press \& Higher Education Press, Shanghai.

[7] Ministry of Education (2007) College English Curriculum Requirements. Shanghai Foreign Language Education Press, Shanghai.

[8] Cai, J.G. (2009) From the Unified and Normative to Personalized and Diversified. China University Teaching, 3, 8285.

[9] Han, Q.S. (1999) Talk about Syllabuses by Restudying the Previous Ones. Foreign Language World, 4, 21-23.

[10] Ministry of Education (2003) High School English Curriculum Standards (Experimental). People’s Education Press, Beijing.

[11] Nunan, D. (1988) The Learner-Centered Curriculum. Cambridge University Press, Cambridge. http://dx.doi.org/10.1017/CBO9781139524506

[12] Feng, Y. (2010) Disciplinary Transfer: Inevitable Choice for Professional Development of Common Core Foreign Language Teachers. University Education Science, 3, 67-72.

[13] Shu, D.F. (2011) Targets and Orientation of the Internationalization of Higher Education and College English Teaching. Foreign Language Teaching and Research, 4, 137-144.

[14] Lu, J.M. (2010) Formulate a Scientific Strategy for Foreign Language Education, and Improve the Language Quality of People. Chinese Foreign Languages Strategy Forum. Shanghai International Studies University, Shanghai.

[15] Mohan, B. and Beckett, G.H. (2003) A Functional Approach to Research on Content-Based Language Learning: Recasts in Causal Explanations. Modern Language Journal, 87, 421-432. http://dx.doi.org/10.1111/1540-4781.00199

\section{Submit or recommend next manuscript to OALib Journal and we will provide best service for you:}

- Publication frequency: Monthly

- 9 subject areas of science, technology and medicine

- Fair and rigorous peer-review system

- Fast publication process

- Article promotion in various social networking sites (LinkedIn, Facebook, Twitter, etc.)

- Maximum dissemination of your research work

Submit Your Paper Online: Click Here to Submit

Contact Us: service@oalib.com 